\title{
硫酸ロジウムめっき液の特徵と用途
}

\author{
珍田 聡 $^{\mathrm{a}}$
}

${ }^{\mathrm{a}} \mathrm{JX}$ 金属商事(株) 高槻工場 ( ₹ 569-0036 大阪府高槻市辻子 3-2-1)

\section{The Characteristics and the Use of Rhodium Sulfate Plating Bath}

\begin{abstract}
Akira CHINDA ${ }^{a}$
${ }^{a}$ Takatsuki Plant, JX Metals Trading Co., Ltd. (3-2-1, Zushi Takatsuki-shi, Osaka 569-0036)
\end{abstract}

Keywords : Rhodium Plating, Rh, Rhodium Sulfate Bath

\section{1.はじめに}

ロジウム $(\mathrm{Rh})$ は 1803 年に白金鉱石から発見された元素で, 現在でも白金鉱石から不純物として産出される。塩の水溶液 がバラ色を示すことから，ギリシャ語でバラ色を意味する

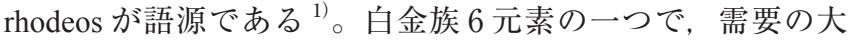
半がガソリン車の排ガス浄化用触媒に使われるとのことであ るが, 産出量自体多くないため, 主流ではない。一方, 電気 めっき皮膜としてはその用途がいささか異なってくる。電気 めっき液は硫酸ロジウムに, 硫酸を加えた比較的シンプルな 組成がベースである。この皮膜は, 従来はジュエリー用途と しての利用が主であった。すなわちロジウムめっき膜は非常 に硬く，銀白色を呈し，また金属アレルギーの報告がないた め，銀製アクセサリーの表面に仕上げめっきとして施される ことが多い。銀は柔らかく傷つきやすいだけでなく，硫化さ れ黒変色しやすいので, その保護膜としてロジウムを薄く めっきするものである。ところで近年，このめっき膜が非常 に硬く，また $10 \mu \mathrm{m}$ を超える厚付けめっき液も開発されて きたことから, 電子部品用途への応用が急速に広がってきて いる。硬さや低接触抵抗性が好まれて, リードスイッチの接 点部に施されていることはご承知と思うが，さらには，スズ と合金化しにくいなどの特性も考慮されて, 電鋳技術を応用 した微細な部品製造(いわゆる MEMS)に応用する例が増え てきている。

しかしロジウムは硝酸, 塩酸, 硫酸などの強酸は元より， 王水にも不溶であるなど, 可溶性塩への加工が非常に困難で あることや，市場規模がそれほど大きくないため，めっき液 を提供できるメーカーが少ない。そのためロジウムめっき液 や皮膜自体への理解が小さいのが現状である。

ロジウムめっき液の欠点の一つとして，めっき膜の内部応 力が高いことによるクラック発生がある。従い, 従来のめっ き液では成膜厚さは $5 \mu \mathrm{m}$ 程度が限界と考えられてきた。当 社では応力緩和成分を合金化させることで，30 $\mu \mathrm{m}$ を超える 超厚付けめっきも可能にしている。本報告では, 従来の薄付 けめっき液と, 厚付けめっき液の特徴を比較しながら, ロジ
ウムめっき液およびめっき皮膜の特性について述べるととも に，適用例のいくつかを紹介する。

\section{2.ロジウムめっき}

従来のロジウムめっき液 (薄付け用) と応力緩和成分を加え た厚付けロジウムめっき液は, 成分も含めて共通項が多いた め, めっき液組成, めっき操作条件, 皮膜物性の項目に分け て比較した。

\section{1 めっき液組成}

めっき液組成の比較を表 1 に示す。薄付けロジウムめっき

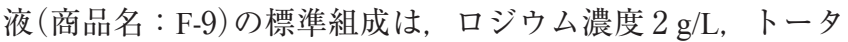
ル硫酸濃度 $45 \mathrm{~g} / \mathrm{L}$ である。これに光沢剂を添加すると優れ た白色美麗な光沢を有し，反射性や均一性に優れためっき膜 を得ることができる。

一方，厚付けロジウムめっき液(商品名:H-8)の標準組成は, ロジウム濃度 $5 \mathrm{~g} / \mathrm{L}$, 硫酸 $80 \mathrm{~g} / \mathrm{L}$ とどちらも薄付け液よりも 高濃度である。また光沢剤は加えない。

\section{2 めっき操作条件}

めっき装置やめっき操作条件などの比較一覧を表 2 に示す。 めっき槽はポリプロピレンやパイレックスガラスなど，耐酸 性, 耐熱性のある材料が望ましい。陽極は白金または白金めっ きチタン材を推奨する。またカートリッジフィルターによる 連続ろ過ができると良い。加熱方法は石英投げ込みヒーター または間接加熱を推奨する。ステンレスヒーターは避けてい ただきたい。

標準的な陰極電流密度は, 薄付けロジウム液は $2 \mathrm{~A} / \mathrm{dm}^{2}$, 厚付け液では $1 \mathrm{~A} / \mathrm{dm}^{2}$ であるが，当然のことながら，擋拌や ロジウムイオン濃度により変動する。めっき液は硫酸による

表 1 ロジウムめっき液組成

\begin{tabular}{c|c|c}
\hline 項 目 & 薄付け液 & 厚付け液 \\
\hline ロジウム $($ III $)$ イオン濃度 & $2 \mathrm{~g} / \mathrm{L}(1.8 \sim 2.2)$ & $5 \mathrm{~g} / \mathrm{L}(4.5 \sim 5.5)$ \\
\hline 全硫酸濃度 & $45 \mathrm{~g} / \mathrm{L}(40 \sim 50)$ & $80 \mathrm{~g} / \mathrm{L}(70 \sim 90)$ \\
\hline 光沢剤 & $10 \mathrm{~mL} / \mathrm{L}(7 \sim 20)$ & 無添加 \\
\hline \multicolumn{2}{|c|}{ かっこ内の数值は適正と考えられる範囲 }
\end{tabular}


表 2 ロジウムめっき操作条件

\begin{tabular}{c|c|c}
\hline 項目 & 薄付け液 & 厚付け液 \\
\hline めっき槽 & ポリプロピレンまたは硬質ガラス \\
\hline 陽 極 & \multicolumn{2}{|c}{ 白金または白金めっきチタン材 } \\
\hline 万 過 & \multicolumn{2}{|c}{ 適 宜 } \\
\hline 加熱方式 & \multicolumn{2}{|c}{ 石英投げ込みヒーター, 間接加熱など } \\
\hline 排気設備 & \multicolumn{2}{|c}{ 局所排気 } \\
\hline 擋 挷 & \multicolumn{2}{|c}{ カソードロッカー } \\
\hline 下地めっき & $\mathrm{Ni}, \mathrm{Pd}, \mathrm{Au}$ またはその合金 \\
\hline めっき液温 & $45^{\circ} \mathrm{C}(40 \sim 50)$ & $60{ }^{\circ} \mathrm{C}(45 \sim 65)$ \\
\hline 㓌極電流密度 & $2 \mathrm{~A} / \mathrm{dm}^{2}$ & $1 \mathrm{~A} / \mathrm{dm}^{2}$ \\
\hline
\end{tabular}

強酸性であるため, 電流効率はあまり高くない。その分水素 ガスが発生するので，局所排気を設ける必要がある。微小部 品にロジウムめっきを行う場合，しばしばバレルめっきが適 用される。しかしメッシュの細かいたる型の容器を用いた海 外ユーザーにおいて競争反応で発生した水素ガスがバレル内 に充満して接触不良を起こした事例がある。このような場合 には，水素ガスをため达まない開放型の傾斜バレルめっき装 置や，皿めっきを適用すると良い。

めっき素材が銅合金，鉄，スズ，洋白などの場合は，密着 性付与のために, 下地めっきとしてニッケル, パラジウム, 金めっきなどを薄く施すと良い。

\section{3 膜特性}

上述のめっき液から得られるロジウムめっき膜の代表的な 特性比較を表 3 に示す。めっき膜厚については, 薄付け液で 試験的に $10 \mu \mathrm{m}$ めっきしたこともあるが，めっき析出時の 内部応力が引張りとなるため, 厚くめっきするとクラックが 入りやすいことから, $5 \mu \mathrm{m}$ 程度までに留めておくほうが良い。 一方, 厚付け液からの析出においては圧縮応力となるため,

$30 \mu \mathrm{m}$ を超える厚付けめっきも可能である。

薄付け液からの析出膜の皮膜純度は $99.9 \%$ 程度であるた め, 電気抵抗は金, 銀, 銅ほどではないが, ニッケルょりも 低く，白金族の特性が出ているものと考元られる。また耐摩 耗性も優れている。これらの性質を活かして, 電気接点など の電子部品への応用展開がなされてきた。一方，厚付け液か らの析出膜の皮膜純度は $95 \sim 99 \%$ と低いため, 電気抵抗が 大きくなることは欠点である。特筆すべきは硬度である。ど ちらの液からもビッカース硬度 (Hv) 1000 程度の超硬質膜が 得られる。溶体金属としてのロジウムの硬度は燒鈍処理が行 われた場合には Hv100 程度と, 特に硬質金属の範ちゅうで はないが，微粒子の集合体であるめっき膜ははるかに硬く仕

表 3 ロジウムめっき膜の物理特性

\begin{tabular}{c|c|c|l}
\hline 項目 & 薄付け液 & 厚付け液 & 測定方法等 \\
\hline 限界膜厚 & $5 \mu \mathrm{m}$ & $100 \mu \mathrm{m}$ & 実績值 \\
\hline 皮膜純度 & $\mathrm{Rh} 99.9 \%$ 以上 & $\mathrm{Rh} 95 \sim 99 \%$ & EDX 分析 \\
\hline 内部応力 & $+180 \mathrm{MPa}$ & $-160 \mathrm{MPa}$ & ストリップ式電着応力測定法 \\
\hline 比抵抗 & $9.2 \mu \Omega \cdot \mathrm{cm}$ & $32 \mu \Omega \cdot \mathrm{cm}$ & $\mathrm{Si}$ ウエハ上測定值 \\
\hline 硬度 $(\mathrm{Hv})$ & 1020 & 1040 & 膜厚 $10 \mu \mathrm{m}$, 荷重 $50 \mathrm{gf}$ \\
\hline 耐摩耗性 & $0.1 \mathrm{mg}$ & $0.2 \mathrm{mg}$ & $\begin{array}{l}\text { \# } 1500 \text { 研摩紙, 荷重 } 500 \mathrm{gf} \\
200 \text { 回スクラチ後のれ量 }\end{array}$ \\
\hline
\end{tabular}

上がるのが特徵である。

\section{3.めっき条件と析出特性}

\section{1 薄付けロジウムめっき液}

当社製薄付けロジウムめっき液において, 種々のめっき条 件が析出特性，特に電流効率に及ぼす影響を紹介する。

3.1.1 ロジウムイオン濃度

ロジウム $($ III ) イオン濃度を変化させた場合の電流効率に及 ぼす影響を図 1 に示す。標準濃度 $2 \mathrm{~g} / \mathrm{L}$ 時, 効率は $40 \%$ 程度 であるが， $4 \mathrm{~g} / \mathrm{L}$ に増やすことで $60 \%$ 程度に向上する。前述 の通り, 硫酸による強酸性めっき液であるため, 電流効率が 低いことは本液の欠点である。ロジウムイオン濃度の増加に 伴い，電流効率が上昇することは，一般的な電気めっき液と 同様である。しかし金属ロジウムが高価であるため, めっき 液の高濃度化はコス卜増につながることから, 完成品のコス 卜や生産方式などを見極めて濃度を選択することが重要であ る。

\section{1.2 めっき液温と陰極電流密度}

めっき液温と陰極電流密度を変化させた場合の電流効率に 及ぼす影響を図 2 に示す。液温を高めるほどに効率が増加し， 液温 $65{ }^{\circ} \mathrm{C}$ では電流密度 $2 \mathrm{~A} / \mathrm{dm}^{2}$ に扔いて, 効率は $60 \%$ 程度

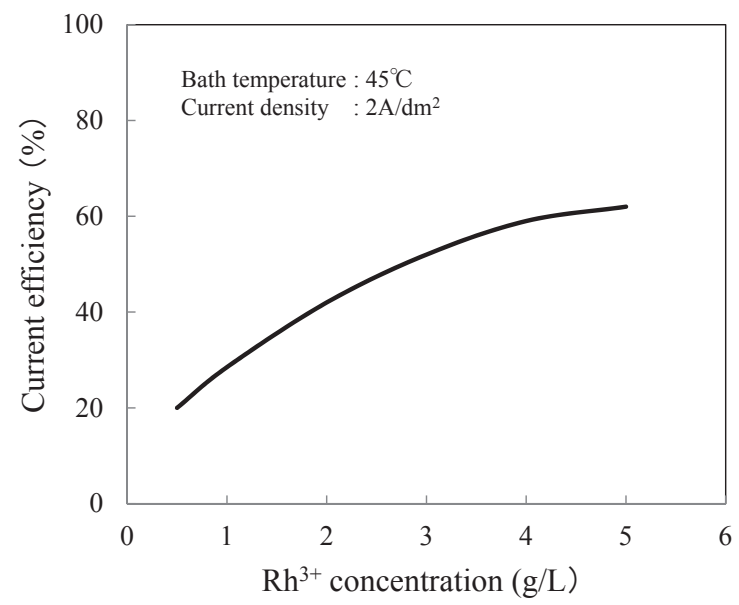

図 1 薄付けロジウムめっき液の $\mathrm{Rh}$ イオン濃度と電流効率の関係

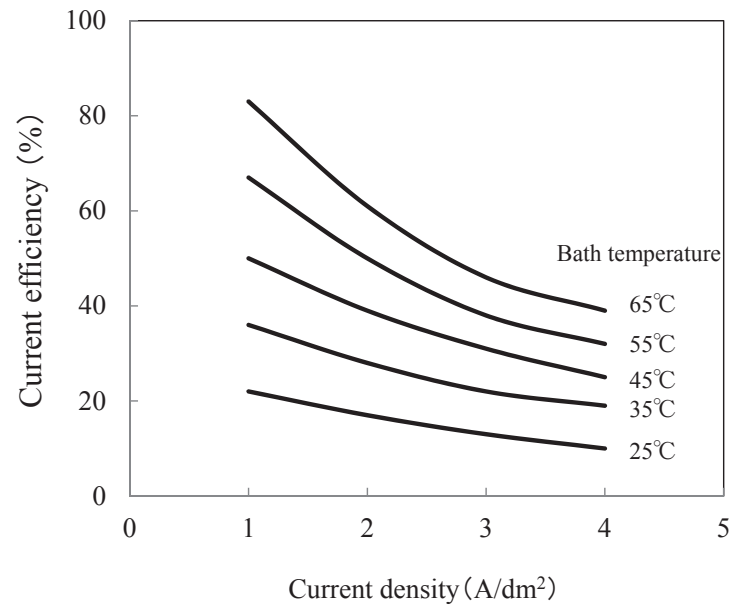

図 2 薄付けロジウムめっき液のめっき液温および電流密 度が析出効率に及ぼす影響 
に上昇するが, 液温が高いと水分が蒸発しめっき液が濃縮さ れてバランスが崩れやすいこと，めっき槽にいっそうの耐熱 仕様が必要なこと, 加熱のための電気代がかさむことなどか ら，液温は $50{ }^{\circ} \mathrm{C}$ 程度までに留めておいたほうが良い。

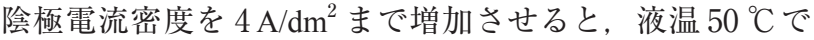
効率は $30 \%$ 程度に低下寸る。従って, 作業性のみを考えて 高電流密度を選択するのは得策ではない。ロジウムイオン濃 度, めっき液温のほか, 擋拌方法についても十分に検討する 必要がある。ロジウムめっき液は高速噴流擋拌のように空気 と接触する機会の多い摚汼方法を受けても, 酸化劣化するよ うな成分は含んでいないため, 大電流密度での高速めっきを 所望する場合には，ジェットめっきもその選択肢として考え られる。

\section{1. 3 不純物の影響}

本液において，めっきに悪影響を与える不純物としては, 銅, 金などがある。これらはめっき皮膜の光沢不良，電着むら， 変色などの原因となるので，混入の経路を詳細に調査し，防 止する対策が重要である。銅についてはもし混入してしまっ たら, 弱電解処理による除去が可能である。またニッケル, 亜鉛，鉄，スズ，塩素イオンなどはあまり影響がないが，電 流効率低下などが起きることがあり決して無害ではないので, 注意が必要である。

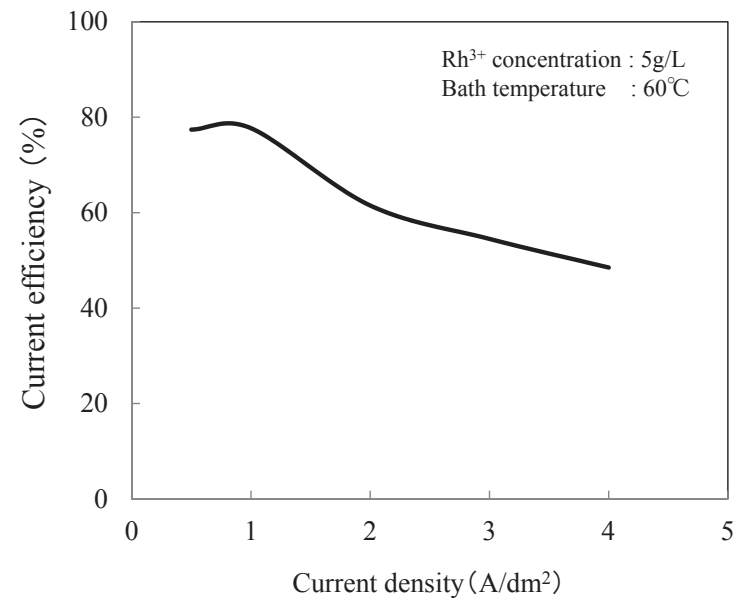

図 3 厚付けロジウムめっき液の電流密度と析出効率の関係

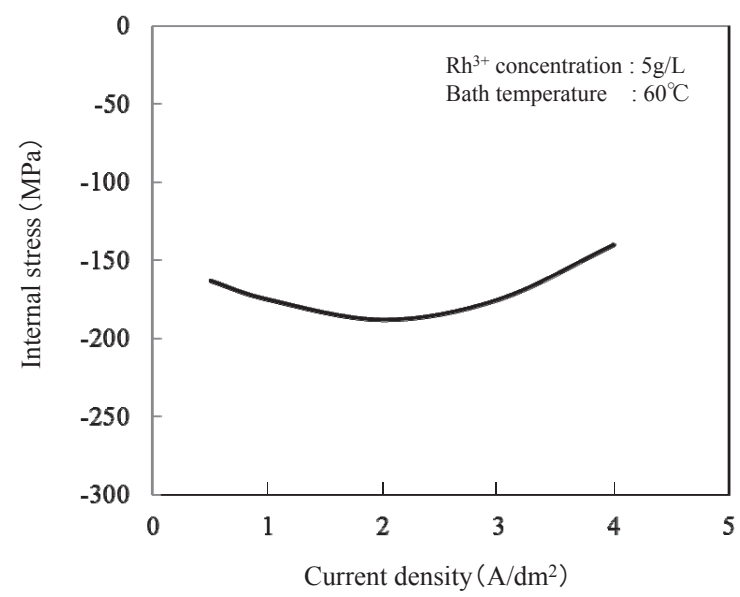

図 4 厚付けロジウムめっき液の電流密度と析出内部応力の関係

\section{2 厚付けロジウムめっき液}

当社製厚付けロジウムめっき液の電流特性を, 種々のめっ き条件を変動因子として紹介する。

3. 2. 1 陰極電流密度と電流効率および内部応力

厚付けロジウムめっき液において, 析出時の陰極電流密度 が電流効率および皮膜内部応力に及ぼす影響について図 3,

図 4 に示す。ロジウム ( III ) イオン濃度は標準条件の $5 \mathrm{~g} / \mathrm{L}$ で のデータである。図 3 から電流密度 $1 \mathrm{~A} / \mathrm{dm}^{2}$ 時の効率は $80 \%$ 程度であるが, 電流密度の増大とともに効率が低下するのは 薄付け液と同様である。一方, 図 4 の析出時の内部応力測定 結果から, 検討した電流密度範囲の $0.5 \sim 4 \mathrm{~A} / \mathrm{dm}^{2}$ において, すべて圧縮応力を示す。すなわち厚付けをした場合でもク ラックが入りにくい特徵が良く示されている。

\section{2. 2 不純物の影響}

厚付けロジウムめっき液においても，めっきに悪影響を及 ぼす不純物は薄付け液と同様であるので，3．1．3 項を参照 いただきたい。

\section{4. 適用例}

\section{1 薄付けロジウム}

ロジウムめっき膜は白色光沢を有し, 硬く傷つきにくいこ とから, 装飾品, 美術工芸品, 時計バンド, 眼鏡フレームな どに早くから使われてきた。また工業用途では耐摩耗部品や 精密機械部品などへの応用がある。その中でも大変優れた用 途がリードスイッチのリード端子への成膜である。リードス イッチの構造概念図を図 5 に示す。リードスイッチとは，接 点端子を持った 2 本の強磁性体リードが相対してガラス管に 封入された構造体である。リードの先端部に予めロジウム めっきを施しておく。接点の酸化劣化を防ぐために，ガラス 管には窒素ガスが封入されている。このリードの軸方向に外 部から磁界を与えると，リード先端の接点が吸着して回路が つながり通電される。ロジウムめっき膜は非常に硬いため摩 耗しにくいこと, 電気抵抗が小さいことなどの理由から, 電 気接点用端子めっき膜として最適であることが，リードス イッチへの採用につながっている。

\section{2 厚付けロジウム}

当社の厚付けめっき液は, 図 4 に示すように析出時の内部 応力が圧縮応力であるため, 従来不可能とされた $10 \mu \mathrm{m}$ を 超える厚付けめっきが可能となった。繰り返しになるが，厚 付けロジウムめっき液から得られるめっき皮膜は, 圧縮応力 であることのほか, 硬質 (Hv1000 程度), スズと合金化しに くいなど, 従来のめっき皮膜では得難い興味深い特徴を有し

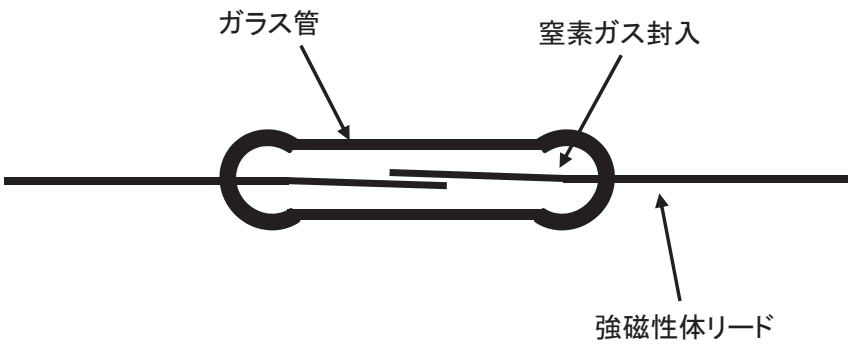

図 5 リードスイッチの構造概念図 
ていることから, 電鋳技術の応用による電子部品製造に適用 され始めている。また試作へのめっき液の引き合いも増えて いる。

今までに試作した微細電鋳部品例としては, 高さ $15 \mu \mathrm{m}$ の微小バンプ, 厚さ $100 \mu \mathrm{m}$ のリング, ステンレス線に厚付 けめっきした後に線を抜いて成形した微細なパイプ状構造体 などがある。写真などで詳細を説明したいところではあるが, 残念ながら試作内容については秘匿義務があるので, 曖昧な 文章に留めさせていただくことをご了承願いたい。

ロジウムは金属アレルギーが出にくい金属の一つであるた め，医療分野への応用も考えられている。

\section{5.おわりに}

ロジウムは白金鉱石の不純物として産出されることなどか ら，もともと産出量が極めて少ない。従い，メ夕ル価格が高 く, また政変, 紛争, 投機などの外的要因によって, 価格が 乱高下しがちである。しかし， ロジウムめっき膜は高硬度， 低抵抗, 高耐食性, スズと合金化しにくいなど, 他の金属めっ
きでは得られないような優れた特長を持っているため, 近年 電子部品業界でも大いに注目されるようになった。

本報告では, ロジウムめっき液を用いる場合の推奨設備, 標準的なめっき条件, 得られる皮膜の特性, 主な用途につい て説明した。一口にロジウムめっき液と言っても, 高純度で 電気抵抗が小さいことが主な長所の薄付け用めっき液と, 応 力緩和成分を含有させて $10 \mu \mathrm{m}$ 以上の厚付けを可能とした 厚付け用めっき液の 2 種類がある。このため, 用途に応じて の液の選択が重要となる。

電子部品業界においては, 薄付け液は主にリードスイッチ の接点形成用に用いられる。また厚付け液は電鋳技術を応用 した微細構造体の製造および試作への適用が最近特に増加し ている。

(Received May 7, 2019)

\section{文献}

1 ）インターネットフリー百科事典「Wikipedia」[ロジウム ] 